DOI: $10.17516 / 1997-1370-0647$

УДК 101.1

\title{
Theological and Epistemological Principles of Ancient Natural Science
}

\author{
Natalia P. Koptseva and Ksenia V. Reznikova* \\ Siberian Federal University \\ Krasnoyarsk, Russian Federation
}

Received 29.07.2020, received in revised form 05.08.2020, accepted 12.08.2020

\begin{abstract}
The article discusses methodology of ancient natural science based on the analysis of the fragment 29cd from Plato's "Timaeus" and Comments on this fragment, which were written by Proclus Dyadochus. Particular focus is on the Plato's views on science as "plausible myth", "probable narration", घikó $\alpha \mu \tilde{v} \theta \mathrm{ov}$. The authors also consider the concept of Sióvor $\alpha$, "dianoetic virtue" in the "Nicomachean Ethics" by Aristotle and Aquinas' Comments on fragments of the"Nicomachean Ethics" where "dianoetic virtues" are examined. Scientific and medical treatises of the great ancient physician Claudius Galen are defined in this article as universal standard of scientific knowledge. The second

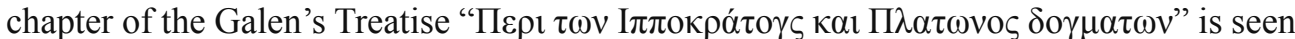
in more detail so that the main constituents of the Galen's scientific method get a full coverage.
\end{abstract}

Keywords: Plato, Aristotle, Aquinas, Proclus Dyadochus, Claudius Galen, "Timaeus”, "Republic", "Nicomachean Ethics", ancient science, the scientific method of Galen, Comments on "Timaeus", Comments "On the Doctrines of Hippocrates and Plato".

Research area: philosophy; culturology.

Citation: Koptseva, N.P., Reznikova, K.V. (2020). Theological and epistemological principles of ancient natural science. J. Sib. Fed. Univ. Humanit. Soc. Sci., 13(8), 1317-1337. DOI: 10.17516/1997-13700647.

(C) Siberian Federal University. All rights reserved

* Corresponding author E-mail address: axu-ta@mail.ru; decanka@mail.ru

ORCID: 0000-0003-3910-7991 (Koptseva); 0000-0003-0889-4582 (Reznikova) 


\section{Theological and gnoseological origin of ancient natural science}

The development of ancient natural science is closely connected with the development of ancient philosophy, with the study of the possibilities of human cognition, with the search for tools for a correct, accurate understanding of the Cosmos and Nature. Ancient Greece is considered the ancestor of modern natural science. This succession is probably rooted in certain cultural and religious customs of ancient Greeks, which distinguished them from neighbouring nations. For instance, the religious thinking of ancient Greeks includes an understanding (along with the concepts of gods, demons, heroes, a variety of animated elements and other religious objects) that there is a universal law, which even gods are subject to. Moreover, these are the gods who establish this universal law for people and monitor how they obey it. Most often it is obviously a moral law. In poem "Works and Days" Hesiod writes: "You kings! Guard against these things and make straight your words, you devourers of gifts! And put crooked dikai out of your mind completely".

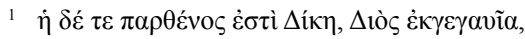

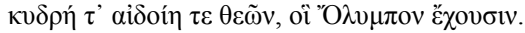

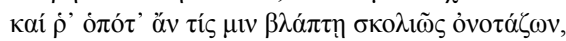

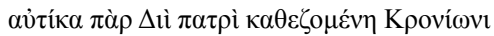

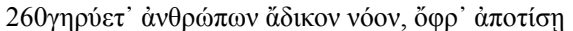

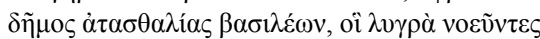

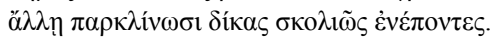
$\tau \alpha \tilde{\tau} \tau \alpha$

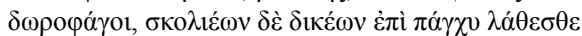

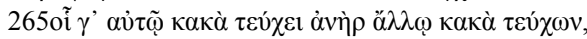

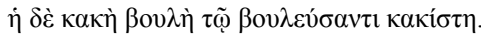

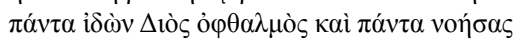

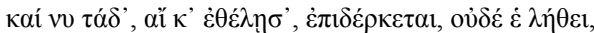

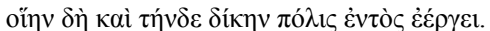

Then there is the virgin Dike, born of Zeus.

She has great esteem and aidōs among the gods who abide in Olympus.

Whenever someone does her harm, using crooked words, right away she takes her place at the side of Zeus son of Kronos,

[260] and she proclaims the noos of men that is without dike, with the result that the people have to pay retribution for the deeds of recklessness committed by their kings. These kings, having baneful thoughts in their noos, pronounce dikai in a crooked way, making them veer and go astray.
Hesiod cites the universal law of dike truth. This law is recognized by Zeus and the other gods. All men follow the universal law. This is not the law of violence, but the law of Truth. An ancient Greek poet and lyricist Theognis of Megara appeals to Zeus himself and asks him why this universal law of Truth is not observed among the people that Zeus rules:

373 Dear Zeus! I marvel at Thee. Thou art lord of all, alone having honour and great power; well knowest Thou the heart and mind of every man alive; and Thy might, O King, is above all things. How then is it, Son of Cronus, that Thy mind can bear to hold the wicked and the righteous in the same esteem, whether a man's mind be turned to temperateness, or, unrighteous works persuading, to wanton outrage? $<\ldots>$ he endureth much shame and yieldeth to Want who teacheth all evil, both lies and deceits and baleful contentions, even to him that will not and to whom no ill is fitting; for hard is the perplexity that cometh of her ${ }^{2}$ (Theognis of Megara)

The desire to know the exact organization of the Cosmos with the aim to understand the universal law governing this Cosmos and human fates creates a need for cognition. This

\footnotetext{
You kings! Guard against these things and make straight your words,

you devourers of gifts! And put crooked dikai out of your mind completely.

[265] The man who plans misfortune for another man is planning misfortune for himself.

A bad plan is the worst plan for the one who planned it. The Eye of Zeus sees all and takes note of all in his noos. If he so wishes, he will watch over the present situation. It does not escape his notice what kind of dike this present dike is that the polis holds within itself.

(Hesiod, "Works and Days" 2019)

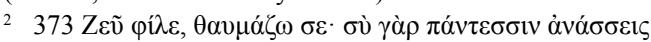

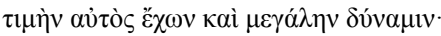

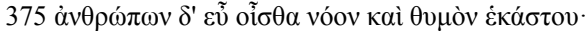

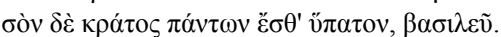

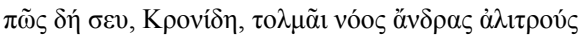

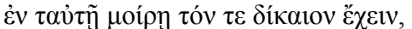

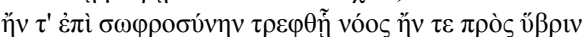

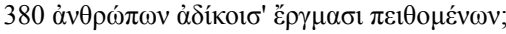

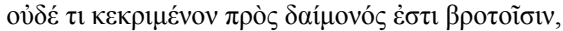

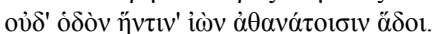


religious and moral need gives birth to philosophy and natural science. Ancient natural science cannot be considered separately from mysterial practices and/or philosophy. Natural science can be seen as an intellectual practice and as a craft, as the activity of people who direct the process of the world cognition based on the inner structure of the world itself. It is hardly possible to grasp a specific method of the scientists of the ancient world without taking into account integrity, logical reasoning and consistency of the ancient world understanding.

The origins of natural sciences in the ancient world lie in the mysterial religion. The ultimate goal of cognition is the achievement of immortality, the transformation of a mortal man into an immortal deity. The goal for both natural science and religion is the same, i.e. $\theta \varepsilon \dot{\varepsilon} \omega \sigma \iota \varsigma$. There are different ways to succeed in that:

5 I've broken free from an ill-fated, painful circle,

Like a quick-legged runner, I've reached the longed-for crown

6 I plunged into the bosom of the Lady, of the Underground Queen.

"Blessed and happy, you will be God instead of a mortal!

(Orphic tablet)

The striving to transform a mortal man into an immortal deity and the search for effective ways to bring a man to $\theta \dot{\varepsilon} \omega \sigma l \varsigma$ beget the whole Hellenic system of cognition, including religious-mystical, philosophical and natural-scientific types of learning. The distinctive features of the natural-scientific cognition of Antiquity are these:

1) rationalism, the study of human abilities in their effort to understand the true structure of the Cosmos;

2) desire to single the signs of the Sacred Unity within the sensual Cosmos, to confirm that even in the untrue and fragmented reality the theologian and philosopher is able to find an incremental way to the Unity;

3) making Good on the anthropological level of being, multiplying the benefits, ex- change of good deeds by people, practical orientation of cognition.

Skepticism is evidently important for natural science, it is typical of ancient scientists and their works are steeped in it. Thus,

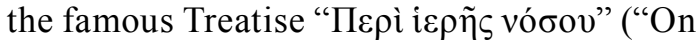
the Sacred Disease") from Hippocratic Corpus begins with a very emotional assessment of those who do not distinguish between "sacred' and "charlatanism": "With regard to the disease called sacred I may say it seems to me neither more divine, no more sacred than others, but rather it has the same nature of origin as other diseases. Its nature and cause are called by some a divine case because of their inexperience and wonder, because it is not at all similar to other diseases"3 (Hippocrates, 1936). Although Galen believed that this work belongs not to Hippocrates himself, but any of his followers, nevertheless he highly valued this text (Hippocrates, 1936: 494).

Theology, philosophy and practical utility were the ancestors of ancient natural science. Theology sets goals for natural science, it gives meaning to its intellectual and other practices, philosophy implies methodological support, and practical activity allows natural science to reproduce the good at the anthropological level of existence. There is a firm belief that the origin of natural science is in magic. A detailed study on this issue was made by G.E.R. Lloyd (1979). Natural science emerges as a kind of magic with the perfected method of obtaining knowledge and with the result that can be reproduced many times (ideally, ad infinitum) in similar starting conditions. This initial connection of theology, philosophy and natural science was destroyed in the New Age science, when metaphysical questions were not regarded within scientific experiments and judgments. However, this does not mean that

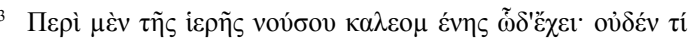

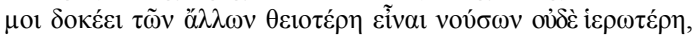
$\dot{\alpha} \lambda \lambda \hat{\alpha}$

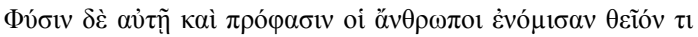

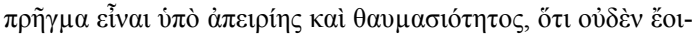

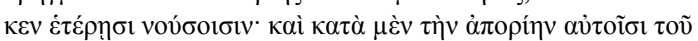

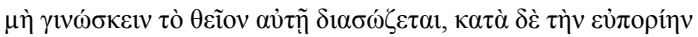

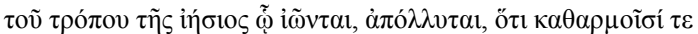
iஸ̃
} 
this connection has disappeared. Even today no one questions paradigmality of scientific knowledge.

In the Foreword to the work "Ancient Cosmos and Modern Science" Alexei Fyodorovich Losev writes about the commensuration of ancient science and modern science:

"Has science ever experienced such an acute crisis and change of physical worldview, as the one we observe now? And has there ever been a debate in science about such fundamental concepts? It is no wonder that many of the physical theories of antiquity emerge, but only in the shell of precise knowledge" (Losev, 1993: 63).

He also points out that ancient science is to be deduced of mystical mythology. By defining Greek philosophy as a logical construction of myth (Losev, 1993: 76), A.F. Losev also introduces the ancient science into this logical construction, into the dialectics of myth. The origin of the conceptual construction of the myth is "Infinity", 'I $\varepsilon \rho$ ó $\varsigma$ $\lambda$ óros, "Sacred Word". A.F. Losev gives the shortest formula for dialectics (both ancient and modern): "The dialectical method consists in consistently distinguishing 'one' and 'another', 'definite' and 'infinite" (Losev, 1993: 104). This restriction is implemented through a number, $\alpha \rho p \imath \mu$ ós.

A.F. Losev states that ancient science is the dialectics of Cosmos, which has 4 origins, 4 sources: 1) "Ether", Monada, Nus; 2) Dyad, primordial matter, apeyron and matter together; 3) Time, Xpóvós, Soul (according to Plotinus); 4) Inevincibility (A $\delta \rho \alpha \sigma \tau \varepsilon \alpha)$, Necessity

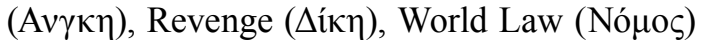
(Losev, 1993: 77-79). Thus, it is possible to evince the wholeness of the ancient knowledge and to understand the ancient natural science as a necessary constituent of the eternal mystery, the dialectics of the limit and the limitless (infinite) which unfolds in the Cosmos itself and in the man who comprehends Cosmos's eidos and merges with it.

Theory and practice were merged in ancient natural science, which is clearly seen in the example of medicine. For the first time the high status of a doctor was described by Homer in "Iliad":

“A wise physician skill'd our wounds to heal, Is more than armies to the public weal"4 (Iliad, 11, 514-515).

It is a different matter that Plato esteemed the development of courts and hospitals not an exuberance, but rather a decline of the state, as this development shows that neither soul nor body of the state citizens are healthy thanks to proper education and upbringing; that citizens need external coercion and treatment.

"It is not the body that is treated by the body, otherwise it would be impossible that doctors themselves could have a bad bodily condition, no, the body is treated by the soul, but it cannot be treated well in such a way. If the doctor's soul is bad or has become such" (Plato, State, 408e).

Cicero, who believed that he should become a Roman Plato, used the image of a doctor along with the image of a helmsman three times in his dialogue "De re publica" ("On the State"); it was done in order to show the meaning of the ruler (Emperor) in the State. For instance, one of the participants in the dialogue, Scipio, while arguing that the state should be ruled by the few best people, tells his interlocutor:

\footnotetext{
"Just as a fair voyage is the intention of the helmsman, the ship is to be entrusted to one helmsman, health of the sick is to be entrusted to one physician (if they both are masters in what they do), it is more rightful than to entrust these things to many" (Cicero, 1994: 77).
}

Comparison with the helmsman and the physician is repeated by St. John Chrysostom, though it is not the governor he compares with the helmsman and the physician, but the God:

"Those travelling by the ship do not give
stern orders to the helmsman how to hold
the helm in a known way and to direct the
ship, but, sitting on the deck, they trust his

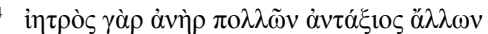

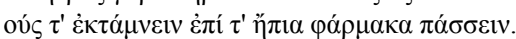


mastery not only when the sea is calm and the ship sails safely, but also when there is a threatening situation; but only in God alone, who cares for us, they are not eager to trust; they can be likened to a sick man, who asks a doctor to give him /her not what stops the disease, but what nourishes the matter which is the mother of the disease" (Chrysostom, 12, 576 (The Word of Diseases and Doctors)).

Either St. John Chrysostom knew Cicero's works well, or the comparison with the doctor and the helmsman may have spread everywhere and was at the time understood by every reader. Therefore, in different epochs this comparison was used either for describing the Emperor (Cicero), or God (St. John Chrysostom), signalling the transformation of the Roman state in the Christian one.

Medical research is a kind of the core of ancient natural science. It brings together the natural, human and divine, here the courageous spirit can find its room in a healthy body:

"...your prayer must be that you may have a sound mind in a sound body.

Pray for a bold spirit, free from all dread of death;

that reckons the closing scene of life among Nature's

kindly boons; that can endure labor, whatever it be..."5 (Juvenal, 2010: 356-359).

Hippocrates believed that medicine had already evolved both in terms of method and content. Having its own methods and content, it provided room for further improvement.

"From olden times medicine has had every means available, it has found both the origin and the method, thanks to which in this long period of time, much wonderful has been discovered and the rest will be found, if someone, being thoroughly prepared and knowing the already found, will strive for

\footnotetext{
5 Órandúm (e)st ut sít mens sán(a) in córpore sáno. Fórtem pósc(e) animúm, mortís terróre caréntem, Quí spatiúm vit(ae) éxtrem(um) inter múnera pónat Náturáe, qui férre queát quos cúmque labóres
}

the research based on the knowledge got" (Hippocrates, 1936, 147, “On Ancient Medicine").

There are all the major characteristics of science: method, specific content, openness to further development. Is it good or bad for medicine to be treated as a science? After all, the same Hippocrates calls it art and says that it has its own artists.

The most important question remains unclear, what was the status of natural sciences in Antiquity? The status of science was to be perceived as "a plausible myth" and "nothing more". Hence the dialogue "Timaeus" outlines the result of application of human cognitive abilities and the sum of knowledge received with their help, i.e. Eíкó $\tau \alpha \mu \tilde{v} \theta$ ov, a plausible myth (a fairy tale, a fable). Is it possible to surmise that during more than a thousand years of history of Ancient Greece, Hellenism, Ancient Rome, Late Antiquity, the status of natural science remained unchanged? The time may not have come to answer the second question yet, nevertheless, the first question is actively discussed in the academic environment.

Suffice it to say that P.P. Gaidenko believes that Plato's reasoning about the "plausible myth" in the dialogue "Timaeus" is a reasoning about natural science, about physics, which cannot claim to be called science to the full extent (Gaidenko). The word "plausibility" is frequent in this dialogue when the astronomer and mathematician Timaeus narrates a story of the Universe from the idea of demiurge and its incarnation in a living being of the Universe to the appearance of people in the Universe. The direct modelling of the Universe in the dialogue "Timaeus" is preceded by the insistent reminder that this modelling is nothing more than عikó $\tau \alpha \mu \tilde{v} \theta$ ov - a probable, believable story:

"On the contrary, we should rejoice if our reasoning turns out to be no less plausible than any other, and at the same time remember that both I, the reasoner, and you, my judges, are only people, and therefore in such circumstances we have to be con- 
tent with a plausible myth, not demanding more"'.

The English translation (by R.D. Archer-Hind) for rendering the expression $\mu \tilde{v} \theta o v$ $\mu \tilde{v} \theta$ ov uses the term "likelihood", i.e. probability, Thomas Taylor in his translation writes "probable narration"; the German translation (made by Franz Susemihl) contains the term "Wahrscheinlichkeit", i.e. probability, likelihood, plausibility, in the translation by S. S. Averintsev we see "a probable myth" (Averintsev, S.S. Timaeus, 29d). Thus, Plato defines science as "probabilistic" knowledge, as "plau-

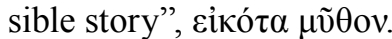

S.V. Mesiats first drew attention to the importance of this definition of science as "a plausible myth", $\mu \tilde{0} \theta$ ov $\mu \tilde{v} \theta$ ov, in her article "Modern Science and Plato's Myth". She asserts that Plato "has guessed all the main features of New European science" (Mesiats, 2007). It is possible that M. Heidegger also thought about science in ancient understanding as an imperfect form of knowledge; he called philosophy after Plato a mistake, which, however, could not have been avoided and which had led European nations to the technical dimension of being" (Heidegger, 1993).

It is known that the dialogue "Timaeus" has been abundantly commented by the Neoplatonians of Antiquity, Middle Ages and Renaissance, as well as by Arab thinkers. The contemporary of Heidegger, the great German physicist Werner Heisenberg, addressed the dialogue in his article "The Meaning of Beauty in Exact Sciences". Heisenberg, as the creator of quantum mechanics, testifies that in the historical debate about the primary elements the winner is Plato with his mathematical ideal forms, and not Democritus, who understood the mainstay of the world as a substance (Heisenberg, 1987: 267-282). That being said Plato for modern science is not so much the author of a successful hypothesis about the primary elements, but the creator of

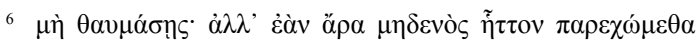

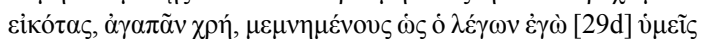

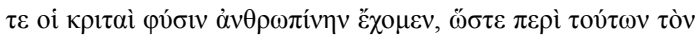

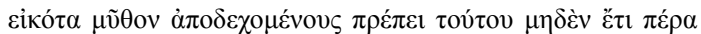
$\zeta \eta \tau \varepsilon \tilde{v}$. scientific meta-theory, philosophy, where the place of scientific natural science is defined in a sufficiently accurate way.

To understand the essence of the theological and philosophical methodology of ancient natural science there shall be analysed the commentary of Proclus Dyadochus on a fragment of the dialogue "Timaeus 29cd", where Plato depicts scientific knowledge as a "plausible myth", probabilistic knowledge, \&i்ó $\alpha \alpha \mu \tilde{\theta} \theta 0 v$.

\section{Comments on the Dialogue "Timaeus" by Proclus Dyadochus, fragment $29 \mathrm{~cd}$. A plausible myth}

A.F. Losev refers to Marinus's remark in Proclus's biography that Proclus was 27 years old when he wrote his commentary on Plato's Dialogue "Timaeus", and that this was probably the first work by Proclus:

"13 By an intense and unresting labor by day and night, he succeeded in recording in writing, along with his own critical remarks, the doctrine which he heard discussed, and of which he finally made a synoptic outline, making such progress that at the age of twenty-eight years, he had composed many treatises, among others a Commentary on the Timaeus, written with utmost elegance and science. Through these prolonged and inspiring studies, to science he added virtue, increasing the moral beauty of his nature" (Marinus of Samaria, 1925).

But A.F. Losev, having indicated that Proclus's commentary contains references to almost all the ancient commentators of this dialogue, supposes that this comprehensive and thorough work, in terms of its coverage of commentators, was hardly written by Proclus in some definite period of his life: "Such a unique work in the history of philosophy, of course, cannot fit into any chronological framework" (Losev, 1988: 37).

Losev highlights that the Proclus's judgment that the dialogue "Timaeus" is a direct continuation of the dialogue "State", and this is very important in the context of the study of platonism as a gnoseological basis of ancient natural science (Losev, 1988: 53). 
The commentary by Proclus's Dyadochus on Plato's "Timaeus" was highly appreciated by Thomas Taylor, an outstanding British researcher and the first translator of Proclus's Dyadochus into English. In the preface to the publication of this commentary T. Taylor posits:

\begin{abstract}
"Of that golden chain of philosophers, who, having themselves happily penetrated, luminously unfolded to others the profundities of the philosophy of Plato, Proclus is indisputably the largest and most refulgent link" (http://meuser.awardspace.com/NeoPlatonics/33700322-Proclus-Commentaryon-the-Timaeus-of-Plato-all-five-books. pdf).
\end{abstract}

Studies of Proclus Diadochus's comments on Plato's "Timaeus" were carried out by the following Western researchers: K.E.A. Schmidt (De Timaeo Platonis ex Procli commentariis restituendo. Stettin. By Gedruckt bie H.G. Offenbart, 1842. 45 p.), Giorgio De Santillana (The origins of scientific thought (from Anaximander to Proclus, 600 D.C. to 300 A.D.). New York. Published by New American Library of World Literature, 1961, 320 p.), Thomas Whittaker (The Neo Platonists a Study in the History of Hellenism. Whitefish, Mont.: Kessinger Pub., 2005, 485 p.), Alain Lernould (Physique et theologie. Lecture du Timee de Platon par Proclus. Villeneuve d'Ascq: Presses Universitaires du Septentrion, c2001. 405 p.), John Phillips (John Phillips Order from Disoder. Proclus Doctrine of Evil and its Roots in Ancient Platonism (Studies in Platonism, Neoplatonism, and the Platonic Tradition. Series editors: Robert M. Berchman (Dowling College, Bard College), and John F. Finamore (University of Iowa), 280 p., Published July 20, 2007 by Brill Academic Publishers), Marije Martijn (Proclus on nature (philosophy of nature and its methods in Proclus' Commentary on Plato's Timaeus). Leiden; Boston: Brill, c2010. IX, 360 p.)

Fragments of the commentary have been translated into Russian by A.V. Petrov (http:// centant.spbu.ru/plat/proklos/works/tim_1/000. htm) and in 2012 line by line "Commentary on "Timaeus" (translated from Greek) was published in Russian (Mesiats, 2012). However, the fragment $29 \mathrm{~cd}$ which is interesting to us has not been published in Russian yet.

Proclus Dyadochus in his commentary on "Timeaeus", 29d, gives a detailed interpretation of this important for understanding ancient natural science thesis of Plato about human science as a probabilistic knowledge, a plausible myth and nothing more. First and foremost, Proclus Dyadochus reveals the gnoseological obstacles associated with the materially incarnate Cosmos. The physical, material Cosmos has been fragmented into many things, the essence of which is just being formed and is not realised within this Cosmos in a holistic and indivisible way. Being an object of cognition, the material Cosmos is not in its true state, but rather in the state of alleged fragmentation, the dissociation of individual things:

"107A Timaeus reminds us in a twofold respect of the privation of stability and accuracy in physical discussions; first, from the essence of the things. For from immaterial natures becoming material, from impartibly partible, from separate natures, such as are situated in a foreign seat, and from universal, becoming individual and partial natures, they do not receive the definition of things scientific and irreprehensible, which is adapted to immaterial and impartible forms"7 (translated by T. Taylor).

The second gnoseological obstacle is related to the cognitive abilities of man, which consist of both sensual sensations and the mind reasoning. Inconsistency, the difference between the form of knowledge and the form of things is the second explanation for the lack of scientific knowledge, according to Proclus Dyadochus:

"But in the second respect, from the imbecility of that by which physical objects are surveyed. For if it be requisite to know any

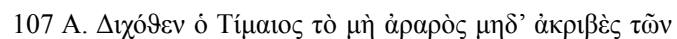

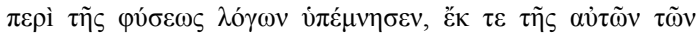

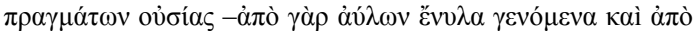

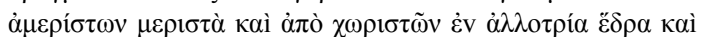

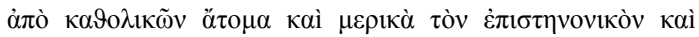

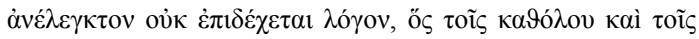

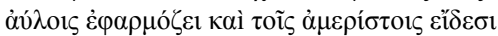


thing concerning them, it is also requisite to embrace a knowledge coordinate to them" (translated by T. Taylor).

Direct human knowledge is sensual knowledge, says Proclus Dyadochus: $\alpha$ $\tau \eta \eta \grave{\varepsilon}$

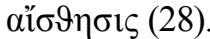

Proclus Dyadochus provides rationale for that human nature alone cannot produce intelligent, pure, holistic knowledge that constitutes unity with things learned. Anthropological forms of knowledge are always distorted by the material substrate through which the cognitive process takes place. It is conceivable that in the material Cosmos there are divine levels of Being, where knowledge and object coincide, nonetheless it is not an anthropological space of Cosmos, but divine one:

"And if indeed we were in the heavens, we should perhaps be less deceived; but here dwelling in the last part of the universe, and being most remote from them, we employ sense in a gross and erroneous manner. For we are allotted the human nature. But the human nature brings with it a life which is material and darkened by the body, and which is partible, and in want of irrational knowledge. The Gods, however, know that which is generated, in a way perfectly remote from generation, that $\mathrm{B}$ which is temporal, eternally, and that which is contingent, necessarily. For by intellectually perceiving they generate all things, so that they intellectually perceive them after the abovementioned manner. For we must not fancy that knowledge is characterized by the natures of the things known"9 (translated by T. Taylor).

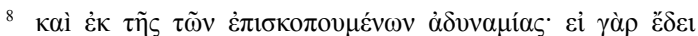

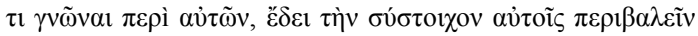

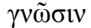

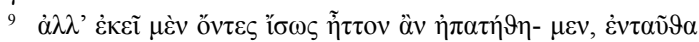

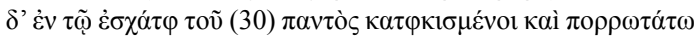

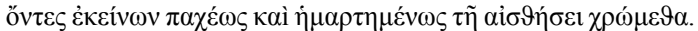

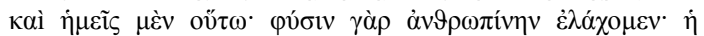

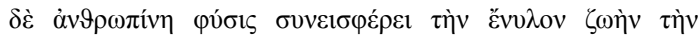

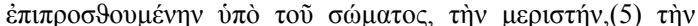

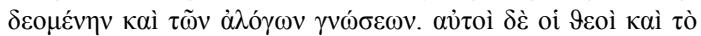

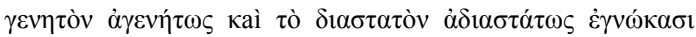

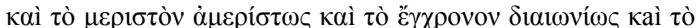

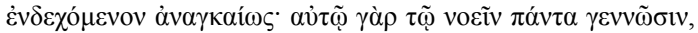

Proclus Dyadochus brings to a logical conclusion his idea of the impossibility of cognition in anthropological status. He maintains that the very thirst for knowledge, the desire to know something is but testifying to the initial and inexpugnable inability of man to know the essence. In true quality, the cognizable and the cognizant are inseparable. Their separation is a distortion per se. In this separation, no cognition can be genuine. Even at the level of gods, cognition is not absolutely genuine, because every god has his own character, his own personality, which distorts the essence, as soon as this essence appears external to the cognizant:

"Hence, our discourses may be very properly said to resemble fables. For our language, which the word "mythos" a fable [used here by Plato] indicates, is replete with crassitude and irrationality, and it is necessary to pardon human nature"10 (translated by T. Taylor).

What is particularly significant here is the "circular" form of commentary on 29d. Proclus Dyadochus, upholding the intermediate conclusion of his interpretation of "the divine Plato", returns to Plato's characterization of

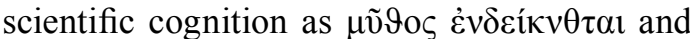
lays down that this is a kind of human destiny, and it is necessary to forgive people for that we are able to create only more or less plausible myth, a fictitious story about the Cosmos and its things, as this is human nature.

Proclus believes that Plato's physics in the dialogue "Timaeus" is superior to Aristotle's. He sees Aristotle's physics as the work of a diligent student who copies the master's work and tries to surpass it:

"It also appears to me that the daemoniacal

Aristotle, emulating as much as possible the

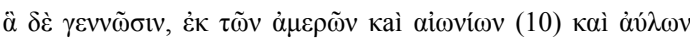

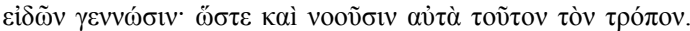

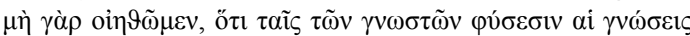

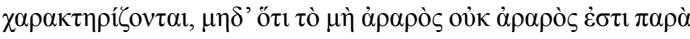
$\vartheta \varepsilon o i ̃ \varsigma$

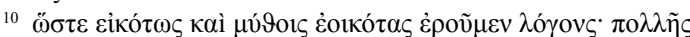

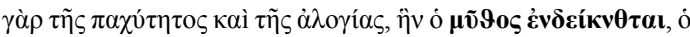

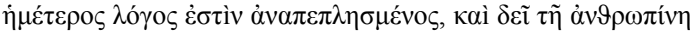

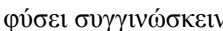


doctrine of Plato, thus arranges the whole of his discussion concerning nature" $(1,2$, F 21-24) ${ }^{11}$ (translated by T. Taylor)

Naturally Proclus believed that Aristotle's physics is grandiose in its conception and execution, but the physics set forth by Plato in the dialogue "Timaeus" has no analogues even in Aristotle's creations (Helmig, Steel, 2012).

The nature science-specific cognition is accomplished by means of certain cognitive abilities, which were analyzed by Plato in the VI book of the dialogue "State" (509d-511e). Plato calls these cognitive abilities $\delta t^{\prime} v o 1 \alpha$, in English this term is translated as "thought", in Russian as "reason" ("rassudok") (A.N. Egunov), in German as "Verstandeserkenntnis".

In the dialogue "State" Plato documents cognitive ability, which produces scientific

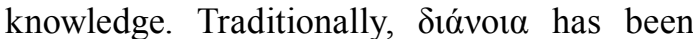
considered a cognitive ability, which is realized through the use of mathematical tools. Plato places it on the second stage after "mind" (vóos). This cognitive ability indeed occupies an intermediate position between sensual cognition, where sensual images are created, and mental comprehension, where eidoses get to the mind. On the basis of sensual images, $\delta$ ióvora does not descend to the lower things, but since it is "burthened" by the sensual im-

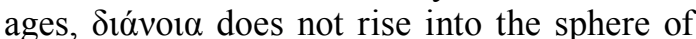
"pure", devoid of images cognition. $\Delta$ lóvora is knowledge based on the sensual image of a fathomable idea. This knowledge which feeds on impulses, assumptions, hypotheses and does not cross their borders, also does not sever itself from these impulses, etc., and from hypothetical sensual images of fathomable eidoses. Plato notices that this is the knowledge of "geometricians" (State, 511d). The intellectually comprehensible knowledge is closest to the Infinity, it does not merge with it, but departs from it in order to formulate logical laws of dialectics and pure abstract concepts for the manifestation of the Infinity.

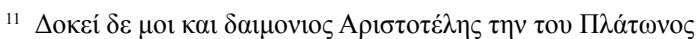

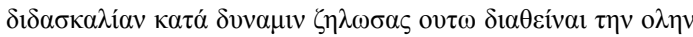

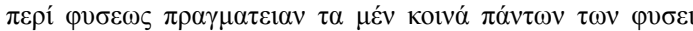

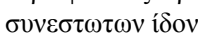

Thus, the gnoseological principles of the ancient natural science were postulated by Plato in his theological and philosophical physics, which he articulated in the dialogue "Timaeus" (it is not without reason that on the fresco "The School of Athens" Rafael painted Plato next to Aristotle, who is holding his book "Metaphysics").

Ancient science is not only a way to document the regularities of the outer world, but also a guidelines of moral behaviour of people, an activity in which the unity of Knowledge and Good is manifested. That is why dióvora gets moral dimension in "Nicomachean Ethics" of Aristotle.

\section{$\Delta$ ıóvola and "Nicomachean Ethics" by Aristotle}

While Stóvora in Plato's dialogue "State" means a certain ("average") educational ability of a human being, in the "Nicomachean Ethics" by Aristotle it presents a generic concept for a certain category of virtues:

\begin{abstract}
"Virtue is divided according to this difference, for we call some virtues intellectual, others moral. Wisdom, understanding and prudence are said to be intellectual virtues, while liberality and sobriety are called moral. When speaking of man's good morals we do not describe him as wise or intelligent but as mild-tempered or sober. We do praise a person for acquiring the habit of wisdom since praiseworthy habits are called virtues"12 (Nichomachean ethics, 1(A), XIII 1103a 5-10).
\end{abstract}

Dianoetic virtues are associated with purely human mental activity, with those processes where a person constructs his / her own judgment. Aristotle distinguishes between the mental activities in which 1) virtue can show by order, encouragement and/or punishment; 2) virtue can arise as a result of a person's own

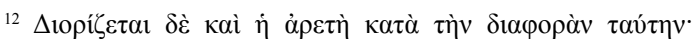

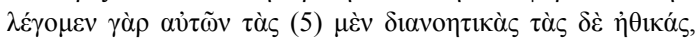

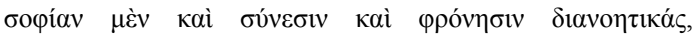

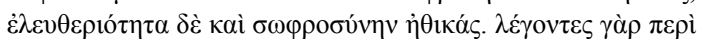

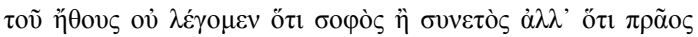

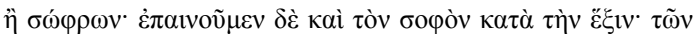

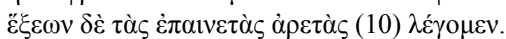


efforts and is therefore purposeful. Moral qualities of the second kind stem from cognitive

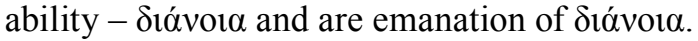

In his Commentaries on "Nicomachean Ethics", Thomas Aquinas emphasises Aristotle's division of the soul into two parts: rational and irrational:

"243. Then [C], at "Virtue is divided," he divides virtue according to this difference in the parts of the soul. He says that virtue is designated or divided according to the above-mentioned difference in the parts of the soul. Since human virtue perfects the work of man which is done according to reason, human virtue must consist in something reasonable. Since the reasonable is of two kinds, by nature and by participation, it follows that there are two kinds of human virtue. One of these is placed in what is rational by nature and is called intellectual. The other is placed in what is rational by participation that is, in the appetitive part of the soul, and is called moral. Therefore, he says, we call some of the virtues intellectual and some moral. Wisdom, understanding and prudence are said to be intellectual virtues, while liberality and sobriety are called moral.

244. He proves this point from human praises. When we wish to praise someone for good morals, we do not describe him as wise and intelligent, but as sober and mild-tempered. We do not praise a man for good morals alone but also for the habit of wisdom. Praiseworthy habits are called virtues. Therefore, besides the moral virtues, there are also intellectual virtues like wisdom, understanding, and some others of this kind. Thus ends the first book. ${ }^{13}$

\footnotetext{
13 (243) Deinde cum dicit determinatur autem virtus etc., dividit virtutem secundum praedictam differentiam potentiarum animae. Et dicit quod virtus determinatur, idest dividitur, secundum praedictam differentiam partium animae. Cum enim virtus humana sit per quam bene perficitur opus hominis quod est secundum rationem, necesse est quod virtus humana sit in aliquo rationali; unde, cum rationale sit duplex, scilicet per essentiam et per participationem, consequens est quod sit duplex humana virtus. Quarum quaedam sit in eo quod est rationale per seipsum, quae vocatur intellectualis; quaedam vero est in
}

(Commentary on the "Nicomachean Ethics" by Thomas Aquinas, translated by C.I. Litzinger, O.P. Chicago, Henry Regnery Company, 1964, in 2 vols, Book 1, Lecture 20).

In fact, Thomas Aquinas simply translates Aristotle into Latin in this comment. But what Aquinas calls "two kinds of reasonable" is crucial here. These two kinds are revealed through analysis of the motives for action of this or that person. A person can act rationally (intellectually) and morally, but because of coercion or habit. And also a person can act rationally and morally in accordance with one's own judgment. We see that Aristotle himself also gives great prominence to this distinction.

In such a way Aristotle and Aquinas introduce into European moral philosophy the distinction between two motives for rational (intellectual) and moral behaviour. In the future, this distinction will be fully elaborated by Immanuel Kant in his theory of hypothetical and categorical imperatives.

The other problems studied by Aristotle and Aquinas are related to the emphasis on the unity of reasonable and moral action, which today sounds like a problem of the moral foundations of science and ontological foundations of truth.

$\Delta$ óvora is "the thinking part of the soul" and it is the only one that defines the "self" of a human being, says Aristotle. He makes this judgment with reference to who the actions of the "good" person are directed at. They are directed at these people themselves, deems Aristotle. Dianoetic qualities of a person make

eo quod est rationale per participationem, idest in appetitiva animae parte, et haec vocatur moralis. Et ideo dicit quod virtutum quasdam dicimus esse intellectuales, quasdam vero morales. Sapientia enim et intellectus et prudentia dicuntur esse intellectuales virtutes, sed liberalitas et sobrietas morales.

(244) Et hoc probat per laudes humanas: quia cum volumus aliquem de moribus suis laudare, non dicimus quod sit sapiens et intelligens, sed quod sit sobrius et mitis. Nec solum laudamus aliquem de moribus, sed etiam laudamus aliquem propter habitum sapientiae. Habitus autem laudabiles dicuntur virtutes. Praeter ergo virtutes morales, sunt aliquae intellectuales, sicut sapientia et intellectus et aliquae huiusmodi. Et sic terminatur primus liber. Available at: http://dhspriory.org/ thomas/Ethics1.htm\#20 
them understand the need for good deeds, which they do for themselves:

"For he is consistent with himself, always desiring the same things with his whole soul; he wishes for himself both genuine and apparent goods, and produces them. Indeed it is the mark of a good man to take pains to achieve the good, and he does this for himself, i.e., for the sake of the intellectual part which seems to be a man's real self.

Likewise, he desires his own life and preservation and especially that of his thinking faculty. For existence is a good to a virtuous man and everyone wishes what is good for him. No one would choose to have everything which exists at the price of becoming someone else. (God even now possesses the good, but he always is what he is at any time.) And it seems that the thinking part of man is the man himself or at least the most important part"14 (Aristotle, Book 9, IV (1166a, 15-19)).

In Aristotle's ethics, dianoetic cognitive abilities predetermine the reasonableness of moral choices, i.e. these very cognitive abilities that make moral behaviour possible as free and responsible in itself. It is worth mentioning that this fragment also reveals a similarity with the Kantian thesis that theoretical reason does not lead to truth (cognitive abilities do not reveal a thing-in-itself), but practical reason directed at itself is capable of acting according to a categorical imperative that turns moral judgment not to the outside but to the inside of a person. The Socratic principle of the unity of mind and morality, knowledge and good is unfolding in the integration of Plato's philosophy of cognition and Aristotle's ethics:

"1804. Next [1, c], at "For he is consistent," he clarifies his principal proposition. First

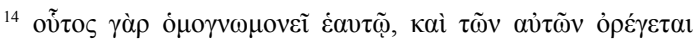

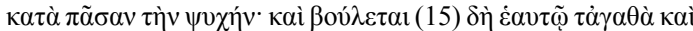

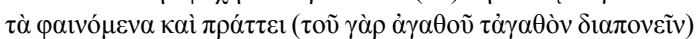

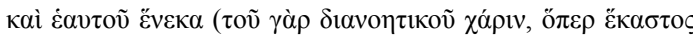

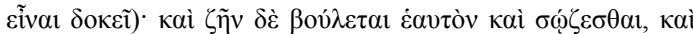
$\mu \alpha ́ \lambda ı \tau \tau \alpha$
}

[c, i] he shows that the virtuous man himself suitably has what is proper to beneficence; second [c, ii], what is proper to goodwill, at "Likewise, he desires etc."; third [c, iii], what is proper to concord, at "Such a man etc." He says first that the virtuous man desires for himself both genuine and apparent goods, for these latter are identical with genuine goods for him; the reason is that he wishes the goods of virtue, the real good of man. Nor is this desire ineffective in him, but he produces these goods for himself because it is a mark of a good man to labor for the achievement of good.

1805. We said in the second book that virtue makes its possessor good and his work good $(222,307,309)$ And the virtuous person wants this and acts for himself, i.e., for the sake of the intellectual element which is foremost in man. Indeed everything seems to be especially what is foremost in it. But the virtuous man strives always to do what is reasonable. It is evident then that he always wishes for himself the absolute good $^{15}$ (Ibid. Book IX. Properties of friendship, Lecture 1. Proportionate Properties in Friendship).

In his Commentary on these fragments of the "Nicomachean Ethics" Aquinas uses Aristotle's reasoning to justify the "naturalness" of man's desire for absolute good. This is the naturalness of the mind, the intellectual aspect of our soul. Aquinas especially accentuates Ar-

15 1804. Deinde cum dicit: iste enim etc., manifestat principale propositum. Et primo ostendit, quod virtuoso convenit respectu suiipsius id quod pertinet ad beneficientiam. Secundo id quod pertinet ad benevolentiam, ibi: et vivere autem vult etc.; tertio id quod pertinet ad concordiam, sed et convivere et cetera. Dicit ergo primo, quod virtuosus maxime vult sibiipsi bona et vera et apparentia. Eadem enim sunt apud ipsum vera et apparentia bona. Vult enim sibi bona virtutis, quae sunt vera hominis bona; nec huiusmodi voluntas in eo est vana, sed huiusmodi bona etiam operatur ad seipsum, quia boni hominis est ut laboret ad perficiendum bonum.

1805. Dictum est enim in secundo, quod virtus facit habentem bonum, et opus eius etiam reddit bonum. Et hoc etiam vult et operatur gratia suiipsius, idest gratia intellectivae partis quae est principalis in homine. Unumquodque autem videtur id maxime esse, quod est principale in eo, virtuosus autem semper ad hoc tendit ut operetur id quod est conveniens rationi. Et sic patet, quod semper vult sibi bonum secundum seipsum. 
istotle's desire to remove the "burden" of virtue from a person. This is not a heavy cross, but personal self-determination, as dianoetic virtue is directed by the mind and it is directed to the mind back. A person who cultivates such a dianoetic virtue as rationality multiplies his/ her beneficence by becoming a rational, reasonable person who minimizes errors in one's own actions.

In this regard, there is an analogy with the current discussion about the status of the university. Certain participants in this discussion have daresaid that a medieval university as a monastery of intellectuals should be replaced by a profitable university-corporation. From the point of view of both Aristotle and Aquinas, the value in itself is the existence of people whose minds predetermine their moral choice in favour of virtue. When such people enter any community this community immanently changes and its overall moral status grows. If such consequences have no monetary equivalent, it does not mean that the university in its original "medieval" sense has no place in modern times.

Plato's thesis that scientific knowledge is an intermediate form of knowledge, "plausi-

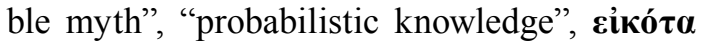
$\boldsymbol{\mu} \tilde{\boldsymbol{v}} \boldsymbol{\theta} \mathrm{ov}$, which will (or will not) be transformed into higher forms in the future cognition by means of philosophy and theology, along with Aristotelian principle of transformation of rational knowledge into practical virtue were taken in by Claudius Galen, the greatest scientist of Antiquity and Middle Ages. Galen's widely known statement that a true doctor/physician is a philosopher without any doubt goes back to Plato, whom Galen revered as a prophet giving the seekers of the Truth all the necessary guidelines. That is why in the treatise "Пврь

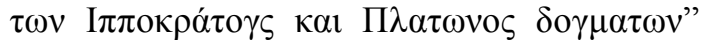
("On the Doctrines of Hippocrates and Plato", "De placitis Hippocratis et Platonis") Galen integrates Plato's theology and philosophy with Hippocratic medical science to prove his own position that mental activity is inherent not only in human, but also in animals, and that the physiology of the higher nervous activity of man is connected not with the heart, but with the brain. Galen's opponent was stoic Chrysip- pus of Soli, author of the treatise "About the Soul", which is known only from Galen's quotation.

The Treatise "De placitis Hippocratis et Platonis" has not been adequatrly studied in both Russian and foreign science. K.J. Elliott refers in passing to the influence of Plato on Galen, saying that it was huge and requires a separate study. According to L. Edelstein, Plato and Hippocrates were like gods for Galen, who likewise worshipped Aristotle. L.T. Pearcy reckons that for Galen Hippocrates and Plato were the founders of real philosophical and medical knowledge. This is also theorized by F. de Lasi, who doubted that Galen's thinking should be attributed exclusively to Platonism. W.D. Smith examines the influence of Hippocrates on Galen, too. I.V. Prolygina only mentions this treatise, noting its more philosophical nature in comparison with other, more practical medical works of Galen. L.T. Pearcy, B.S. Eastwood, N. Arikha, T.J. Tracy, E.A. Puchkova, G.C. McDonald. D.A. Balalykin, A.P. Shcheglov, N.P. Shock study to the very Trea-

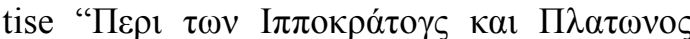
$\delta$ o $\mu \alpha \tau \omega v "$ and figure that Galen is the last element in one of the two main methodological and gnoseological lines of the development of ancient natural science: Plato - Hippocrates Aristotle - Galen (the other line: Leucippus Democritus - Epicurus - Asclepiades); they presume that the study of Galen in Russian academic environment is complicated by the small number of treatises of the Roman philosopher translated into Russian. In particular, they say that there are only translations of the work on the usefulness of the parts of the body.

Preliminary analysis of Galen's Trea-

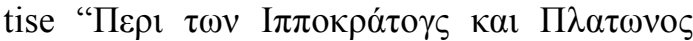
$\delta o \gamma \mu \alpha \tau \omega v$ " has evinced that this is a brilliant example of ancient natural science knowledge, a universal standard of presentation of scientific ideas and their proofs. The greatest advantage of this treatise is the integration of philosophical methodology and empirical evidence, which Galen obtained with the help of his huge anatomic practice. Even main ideas of this treatise cannot be presented in this small article, so only Book 2 was chosen for the further analysis of Galen's scientific method. 


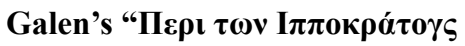

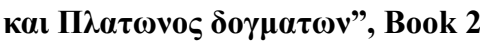

In Book Two, Galen begins with the natural science method. He cites his treatise "On Evidence" and says that each statement must be based on reliable sources and strict method. Galen enters in polemics with Chrysippus, who, in order to "verify" that the human soul (i.e. mental activity) has the source in heart, resorts to "strange" arguments - quotes from poets, etymology of words, as well as the physical movements that accompany pronunciation of the words "I", "ego". According to Chrysippus, these movements of a mouth and jaws point downwards, to the chest, where the heart is. In spite of Galen's rejection of this method of proof, he avers that it is possible to refute Chrysippus himself with such reasoning. For example, when people want to express their consent, they nod their head. Why, Galen quirks, should one pay attention to the direction of that nod down and not up? And why should we pay heed to the movements that make up this nod and not to the fact that it is the head that moves, not another part of the body? So, by rebutting Chrissippus's arguments in their essence, Galen nevertheless tries to "speak the language of the interlocutor" and deflates it in the way that his opponent applies.

But then, disaffirming this method of "proof", Galen constructs his own reasoning and at the same time reveals to us the framework of his scientific thinking. Galen assumes that in order to explore the essence, one must look at how this research was conducted by the "ancient" authors. The essence is not somewhere, but in what is the direct object of research:

"The controlling part of the soul, with which many can agree, is a source of feelings and ability to volitional actions. Therefore, the proof that the heart possesses the controlling part of the soul should not proceed from any other premise than the fact that any conscious (volitional) movement of any part of the body starts in it, and all the feelings return to it" (Galen, 2005: 3, 4-5).
Next Galen goes straight on to the proof that he considers indisputable: anatomical incision exposes the heart and makes it possible to see (if there is one) a certain vessel that connects the heart to those organs that are in motion:

"...the method of scientific evidence has made clear that it would be more useful to cut through the animal's flesh and directly observe which and how many varieties of structures originate in the heart and spread to all other parts of the animal; and to observe these very structures, of which there are so many in number and varieties; this one, for example, is responsible for a feeling or movement, or both at once, that is in charge of something else, and thus we can reach an understanding of what forces in the body have their source in the heart" (Galen, 2005: 3, 7).

Galen points out that the base of his scientific method is Aristotle's "Posterior Analytics", which states that knowledge of new should be based on knowledge obtained earlier. Both the previous knowledge and the new knowledge must be directly related to the subject itself, with its internal properties.

Galen begins his research on whether the heart is the source of the physiology of higher nervous activity with a brief theoretical discussion about which arguments are scientific and which are unscientific in their nature. He attributes to unscientific arguments such varieties as "rhetorical" and "sophistic". Moreover, Galen supposes that "scientific" arguments, which are based on knowledge about the heart, should be analyzed in a special way.

Among other things, there is an argument that the heart is anatomically in the middle of the human body. On this Galen opines that neither the fact that heart is in the exact middle of the human body nor the fact that the brain occupies the highest position in the human body are arguments to choose the heart or brain as the sources of sensation and motor activity of a living being.

Further, Galen explores the tenet that the heart and lungs situated near the heart give 
rise to human speech. Galen's arguments are purely experimental in nature. He tells about an experiment with a severed trachea in an animal and a wounded person. If the trachea is cut, says Galen, and the heart and lungs are left untouched, the animal and the man will stop making sounds. The source of sounds is the larynx. And although air is involved in the production of the voice, Galen concludes, it is inside the larynx where air makes the sounds. Without the larynx, air movement is involved only in breathing, not in sounds and speech.

Galen's next argument is also an experimental and empirical one. He sees it as an undeniable fact that certain muscles are involved in the production of sounds and speech, and it is their tension which sends air into the trachea. But even earlier, the tension of these muscles creates a nerve that is everywhere, in every muscle. If you cut this nerve, the muscles will never strain and will never create the possibility of movement for the air flow.

Finally, the third experimental and empirical argument is conditioned by the fact that pushing air into the larynx may involve different sets of muscles, depending on the mental state of the person. If a person is calm, then the speech production is connected with the activity of one "set" of muscles, if a person is anxious, the air is pushed into the larynx by other muscles. Galen goes on to say that at the same time this process can be shown by means of anatomy: if you cut certain nerves, then neither muscle will move, although the heart, lungs, trachea, and the other organs will be in full order. Additionally, Galen is very precise in specifying which nerves can be cut at the neck or head, or while pressing the brain or the left ventricle of the heart, so that the corresponding muscles will lose their ability to move.

Galen exemplifies it by describing the behaviour of animals being sacrificed. When their hearts are removed, they are still able to make sounds, scream, and move, although they will die of blood loss very quickly. Conversely, if you cut the bull's spinal cord where it connects to the brain, even though the animal's heart is perfectly fine, it loses the ability to move, breathe and pronounce any sounds.
Then Galen advances many other arguments and dissents with a number of scientists who argue that it is not the brain that is the source of sensations, and that since the heart is the source of meaningful speech, it is the heart that generates thinking. The thing which is noteworthy here is confidence of both Galen and those with whom he argues that intelligent thinking is a form of meaningful and structured speech.

Galen takes a very detailed look at the "sophistic" argument of Zenon, the founder of Stoicism, who insists that if a voice arises when the air flow passes through the respiratory throat, it is not the brain that sends it there and, therefore, it is not the brain that is involved in the production of meaningful speech, eventually, it is not the brain that is the human mind organ. As opposed to Zenon's sophism Galen formulates his own medical sophism: "If urine was sent by the heart, it would not be pushed through the genitals". He invites his opponents to consider this thesis as applied to their own claims about the brain and larynx.

What draws attention is the way Galen combines logical reasoning and experiential and empirical data. For example, he decomposes the argument that it is the heart which controls our senses, because the senses are very close to the heart. And Galen demolishes similar arguments about the brain - like that the brain is the source of visual and auditory sensations, because the eyes and ears are close to the brain. For Galen, the means of proof are no less important than the conclusions drawn from this evidence. The proximity of different organs cannot indicate that some neighbouring organs are a source of sensations that occur in other organs close to the former. Galen asserts that the "close proximity" argument violates the universal law of logic:

"The proximity of location, misleading both sides, accredits the preconditions with the facade of science and evidence; but this is not the truth. Take a man who believes that the heart is the source of all things, the remoteness of his eyes from heart will not prevent him from having faith in that they too receive the sensation and move- 
ment from the heart being the source of any sensation and movement; and a man who claims that the source is the brain insists that no one of the other organs is the source of movement in the respiratory and speech organs, and so it is the brain that begets a volitional movement in them as in everything else.

It turns out that the universal statements we have been taught as regards the methods of evidence are true only in particular cases and this is true for every subject of study. Prerequisites shall incorporate only the properties relevant to the problem instead of the truthful data on all the properties of the object" (Galen, 2005: 5, 44-47).

Teaching and practice, Galen says, are the main sources of truth. Using logical reasoning, he spent a lot of time and wrote a lot of pages on debunking the arguments of Zenon, Diogenes and Chrysippus, representatives of Stoic psychology. Galen reprehends not doctors who have anatomical and treatment practices, but philosophers who do not rely on medical facts in their thinking. He fights them with their own weapons, revealing the logical inconsistency, sophistry of their pseudo-reasoning; primarily he draws the arguments of medical practice and the logicality of adducing proofs.

Galen was very critical about Chrysippus's claim that the heart could transmit impulses to the brain so that the brain, which controls all the nerves, could cause this or that sensation. Previously, Galen had referred to his previous writings and arguments set forth in other treatises. In this treatise, we can trace the course of his research and methods directly, as Galen reproduces the course of this research in fine detail.

\section{$I^{\text {st }}$ step. The experimental stage with designing} the experience

"The number and nature of the structures that connect the heart to the brain must be determined when cutting the animal; then each of these structures in the neck region shall be cut or flattened or bandaged with the ligature to observe the effect this action will have on the animal" (Galen, 2005: 6, 3-4).

$2^{\text {nd }}$ step. Using previously obtained reliable knowledge about the subject of the study

"The heart is connected to the brain by three types of vessels that are common to the whole body: veins, arteries and nerves; the veins are the so-called jugular veins, arteries, carotid artery, and the nerves that are located outside these arteries" (Galen, 2005: 6, 4-5).

$3^{\text {rd }}$ step. Validation of basic knowledge in practice (anatomical)

"You cannot just cut the jugular vein or carotid artery as we do with nerves, because the animal will quickly die of heavy bleeding; it is better to start by bandaging them with good ligatures in the upper and lower parts of the neck, and then make cuts between ligatures, thus avoiding bleeding. As for the nerves, whether you wish to flatten them or bandage with ligatures, or clamp them with your fingers, all these operations will have the same effect on the animal: it will immediately lose its voice, but no other activity will be disturbed; neither immediately nor later. Having experienced bandaging with the ligature or cutting of the arteries in the described way, the animal will lose neither voice nor sensitivity, as most of the proponents of Hippocrates wrote, because of their wrong cuts, but all the arteries over the wound will lose heartbeat. Again, even if you clamp the veins with ligatures or if you cut them in the way described above, you will not see that any activity (function) is hurt" (Galen, 2005: 6, 5-8).

$4^{\text {th }}$ step. Reasoning built on logical laws, based on different preconditions and on that a certain assumption may lead to

"that the heart does not have a leading source of its strength in the brain, you would learn from the fact that when all the above mentioned nerves are either cut or tied by ligatures, the animal only loses its voice; this animal inhales and exhales without any trouble concerning both inhalation and exhalation, which were mentioned earlier, and even now keeps moving all its four limbs, as well it hears, sees, and feels 
as before. It happens, as we said, when the nerves along the arteries are cut and only the animal's voice is hurt" (Galen, 2005: 6, 10-12).

$5^{\text {th }}$ step. Discussion, rebuttal or confirmation of the opinions of scientists and philosophers who expressed certain views on the subject

"All those doctors and philosophers who believed that by cutting or clamping the mentioned arteries in the described way, the animal loses its sensitivity, and who further concluded that the heart excites the sensitivity and movement to the brain, should be seen as having made a mistake in their study of the phenomenon, though they had made an accurate conclusion based on their assumption" (Galen, 2005: 6, 13-14).

$6^{\text {th }}$ step. In the course of the discussion, Galen singles out in the opinion of opponents both a rational grain and a delusion, then he approaches the evaluation of opposite opinions in a constructive way, chooses in them what can be used to confirm his own position.

"The truth is that we cannot perceive sensually that the controlling part of the soul is enclosed either in the chest or in the heart, and therefore I praise the original statement of Chrysippus, in which he acknowledges the truth, but I do not welcome his statement in which he gives a false description of the sensual perception" (Galen, 2005: 6, 15-16).

$7^{\text {th }}$ step. Concrete scientific knowledge is transformed into philosophical one, because in the course of the research it has demonstrated its limitations and stochastic approximation; to transform concrete scientific knowledge into philosophical one Galen refers to the universal concept of Plato's soul found in the dialogues "State" and "Timaeus"

"I am going to prove that the rational (endowed with mind) part of the soul, which Chryssipus himself calls the "controlling part", the "mind" and the "supreme controlling part of the soul" are in the brain. Once this has been proven, if we see that there is another power in the heart that does not come from any other source, we will get a clear idea of the first (main) two principles and then, as a consequence, we will discov- er the third in the same way" (Galen, 2005:

6, 20-21).

Thus, the medical and anatomical part of Galen's research passes through to the philosophical part, where he makes his own comments on Plato's dialogues "State" and "Timaeus". Previously, there was made an assumption that these Plato's dialogues were the main methodological-philosophical basis for Galen and maybe other researchers who have got ahead in the ancient natural science. It is possible to hypothesise that the real ancestor of modern natural science is more Plato than Aristotle, as it is commonly believed in modern science tradition. Galen's comments on Plato's “Timaeus" and "State" dialogues are not included in Book 2 of the Treatise being analysed now and should be the subject of further research.

From the beginning to the end the whole Book 2 is devoted to the logically constructed arguments of Galen, who has set himself the goal to prove the following thesis:

\begin{abstract}
"The rational (endowed with the mind) part of the soul, which Chrysippus himself calls the 'controlling part', the mind and the supreme controlling part of the soul are in the brain" (Galen, 2005: 7, 20).
\end{abstract}

Galen's reflection over his evidence (as well as his opponents' consideration on the matter) is of great interest. He distinguishes 4 types of evidence:

"The first type I called scientific and demonstrative, the second - useful for training and, as Aristotle would say, dialectical, third - persuasive (motivating, stimulating) and rhetorical, and the fourth - sophistical; and I have shown that the prerequisites, which are based on the qualities and characteristics of the heart, which are directly related to the very essence of the problem under study, belong to the class of scientific prerequisites, and all the others are dialectical; those prerequisites which are taken from external evidence are rhetorical, and those that deceptively exploit homonyms or forms of expression are sophistical" (Galen, 2005: 8, 2). 
Galen sees as scientific evidence those that are based on a direct study of the object, which are related to the clarification of its internal, inherent properties:

\begin{abstract}
"As for the scientific prerequisites relevant to any issue, they are very few and easy to count, but those that are useful for training, are numerous, they are formulated based on any quality and properties of the thing" (Galen, 2005: 8, 3-4)
\end{abstract}

Book 2 ends with another rede by Galen, where he scrutinizes the argument of his rivals in a discussion about whether the "controlling soul" is in the heart or the brain. Galen formulates the argument of his opponents in the following way:

\footnotetext{
"The organ from which the animals' originating source comes also contains a reasonable part of the soul; the animals' originating source is in the heart; hence the part of the soul which reasons and thinks is also in it" (Galen, 2005: 8, 33-34).
}

Galen refutes this argument with the following premises:

1) he points out that the thesis about the heart as an originating source (of power) has not yet been proved by anyone and that the previously unproven thesis should not be used as an argument; Galen reports that the corroboration about the source of power will be made in the next books of this Treatise;

2) he constates that there is no direct connection between the originating source and the part controlling the will;

3) then he examines probable quality of this connection, e.g., the argument that it is the heart that is the first to consume the power; this is a false argument, which Galen proves with numerous examples; the mouth, oesophagus, stomach, are the first to be fed / to get the power, besides, air flow comes first not to the heart but to the mouth, throat and lungs;

4) and finally, in the arguments of his opponents Galen chooses what is able to prove his own position; indeed, what is important is not the food itself, but the controlling centre, which will lead to our willingness or unwillingness to eat.

5) Book 2 of the treatise concludes with a clear indication by Galen that it is not speculation that should be taken into account, but "anatomical observations".

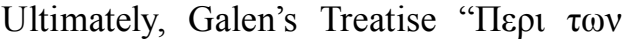

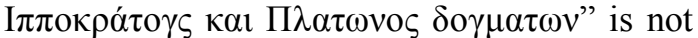
first and foremost a philosophical work; Galen clearly distinguishes between "dialectical" and "scientific" prerequisites. And he formulates his task in a very accurate way: to conduct purely scientific research based on a specific scientific (in this very case - anatomical) methodology. One can see that the entire second book of this Treatise is devoted to the anatomical experience and even experiment. In the part where Galen makes assumptions about which organs are actually connected with the movement and will of a living being, he proposes to perform various medical operations with the organs of the animal and monitor what this or that anatomical doctor's action will lead to.

Galen's philosophical arguments in this Treatise are "diffused" among his inferences. They predetermine a clear logical order of his reasoning. He himself is attracted to the "ancient" authors (which for him are Hippocrates, Plato and Aristotle) with their clarity and logic of their philosophical constructions and conclusions. The second book fortifies that Galen conducted sufficiently developed medical experiments related to cranial trepanation, spine transection, he knew which parts of the brain are responsible for the movements of living beings.

In Galen's works, ancient natural science has reached its peak of development. The combination of philosophical method of reasoning, reliance on experience and experiment, the ability to organise a rational discussion with opponents, including singling out of arguments to defend his position from the opponents' claims, a fastiduous analysis of scientific methodology and reliance on the perfect logic of great thinkers, all these qualities put Galen above all other thinkers in the discussed space of ancient natural science.

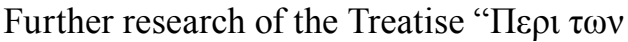

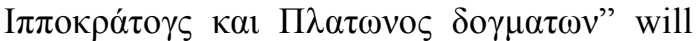


help to clarify Galen's methodology on the solution of other scientific problems, as well as to reveal his role as a philosopher with thorough consideration of his particular comments on the Plato's dialogues "Timaeus" and "State".

Summing it up, though it is a well-known fact that Galen's ideas influenced the development of medicine, and this influence had been felt for at least for about one and a half thousand years, the works of this late antique author are also important for the formation of science as a whole. Galen's Treatise under study is a model of natural application of scientific method, based on empirical data and philosophical methodology. Practically, Galen's Treatise is nothing but the standard of scientific cogni- tion embodied in the text, syncretism of purely practical component and philosophical, moral principle. Here scientific cognition is no longer a plausible myth, but, relying on the logic of philosophy and setting its goal the good for a human being, it is transformed into other knowledge, which helps making a concrete step towards $\theta \dot{\varepsilon} \omega \sigma i \varsigma$.

Referral to ancient thinkers is as natural for Galen as his incessant references to the results of anatomical studies. The Aesculapian in Galen's perception is certainly a philosopher; representatives of any other scientific spheres as well must have shared the idea of this inseparable unity of universal worldview goal setting and empirical foundation.

\section{References}

Aquinas, Th. Kommentarii k "Nikomakhovoi etike" Aristotelia [Comments on the "Nicomachean Ethics" by Aristotle]. Available at: http://dhspriory.org/thomas/Ethics1.htm\#20

Arikha, N. (2008). "Just Life in a Nutshell": Humours as Common Sense. In The Philosophical Forum Inc.: 303-314.

Aristotle. Nikomakhova etika [Nicomachean Ethics].

Balalykin, D.A., Shcheglov, A.P., Shok, N.P. (2013). Naturfilosofskaia traditsiia antichnogo estestvoznaniya i aleksandriiskaia shkola v III veke. Chast' I. [The natural philosophy tradition of ancient natural science and the Alexandrian school in the $3^{\text {rd }}$ century. Part I]. In Filosofiia nauki [Philosophy of Science], 2 (57), 157-175.

Balalykin, D.A., Shok, N.P., Shcheglov, A.P. (2013). Sootnoshenie dukhovnogo i fizicheskogo v ponimanii Galenom zdorov'ia i bolezni. Chast' I (na primere raboty "Sposob raspoznavaniia i lecheniia strastei liuboi, v tom chisle i svoei sobstvennoi dushi") [The ratio of the spiritual and the physical in Galen's understanding of health and illness. Part I (on the example of the work "A way of recognizing and treating any passion, including of one's own soul")]. In Istoricheskie nauki [Historical Sciences], 7. Available at: http:// www.online-science.ru/m/products/istori_sciense/gid888/pg3/

Braginskoi, N. (1997). Filosofy Gretsii [Philosophers of Greece]. Moscow: Publishing house EKSMO-Press.

Chrysostom, J. (1895, 1906). Tvorenia sv. ottsa nashego Ioanna Zlatousta, arkhiepiskopa Konstantinopol'skogo, v russkom perevode [The creations of St., Our Father John Chrysostom, Archbishop of Constantinople, in Russian translation], 1-12. St. Petersburg.

Cicero Marcus Tullius (1994). Dialogi "O gosudarstve”, "O zakonakh" [Dialogues "On the State”, "On the Laws"]. Moscow, "Nauka".

Commentary on the Nicomachean Ethics by Thomas Aquinas, translated by C.I. Litzinger, O.P. Chicago: Henry Regnery Company, 1964, 2 volumes, Book 1, Lecture 20. Available at: http://dhspriory.org/ thomas/Ethics1.htm\#20

Eastwood, B.S. Galen on the Elements of Olfactory Sensation, 268-290. Available at: http://www.rhm. uni-koeln.de/124/Eastwood.pdf

Edelstein, L. (1967). Ancient Medicine. Baltimore, MD: Johns Hopkins University Press.

Elliot, K.J. (2005). Galen, Rome and the Second Sophistic. Thesis for the degree of Doctor of Philosophy.

Gaidenko, P.P. "History of Greek Philosophy in its connection with Science". Chapter 5.17. In Kosmologiia i fizika Platona. Poniatie materii [Cosmology and Physics of Plato. The Concept of Matter]. Kos- 
mologiia i fizika v dialoge Platona "Timey" [Cosmology and physics in Plato's "Timaeus" dialogue]. Available at: http://philosophy.ru/library/gaid/62.html

Galen (1978-1984, 2005). De placitis Hippocratis et Platonis, edidit, in linguam Anglicam vertit, commentatus est Ph. De Lacy, CMG 4,1,2,3 vol., Berlin 1978-1984; vol. I: edition tertia lucis ope expressa, vol. II: edition altera Lucis ope expressa, vol. III: edition altera lucis ope expressa addendis corrigendis aucta, Berlin.

Green, Ch.D. (2003). Where did the Ventricular Localization of Mental Faculties Come from? In Journal of History of the Behavioral Sciences, 39 (2), 131-142

Heidegger, M. (1993). Evropeiskii nigilizm [European nihilism]. In Martin Khaidegger, Vremia i bytie (seriia "Mysliteli XX veka") [Martin Heidegger, Time and Being (series "Thinkers of the $20^{\text {th }}$ century")]. Moscow, Publishing House "Respublika".

Heisenberg, W. (1987). Shagi za gorizont [Steps beyond the horizon]. Moscow, Publishing House "Progress".

Helmig, Ch. and Steel, C. (2012). Proclus. In The Stanford Encyclopedia of Philosophy. Available at: http://plato.stanford.edu/archives/sum2012/entries/proclus/

Hesiod. (2019). Works and Days. Translated by Gregory Nagy. Center for Hellenic Studies. Harvard University. Available at: https://chs.harvard.edu/CHS/article/display/5290

Hippocrates (1936). Izbrannyye knigi [Selected books]. Gosudarstvennoe izdatel'stvo biologicheskoi i meditsinskoi literatury [State publishing house of biological and medical literature].

Homer (1903). Iliad. Book 11. Transl. by Alexander Pope. In Complete Poetic works. Available at: https://www.sparknotes.com/lit/iliad/full-text/book-xi/

Juvenal (2007). Satire 10. Translated by L. Ewans (1889). Formatted and with notes by C. Chinn (2007). Available at: http://pages.pomona.edu/ cmc24747/sources/juvenal/juv 10.htm

Lacy, P. de (1972). Galen's Platonism. In AJP, 93, 27-39.

Lernould, A. (2001). Physique et theologie. Lecture du Timee de Platon par Proclus. Villeneuve d'Ascq, Presses Universitaires du Septentrion.

Liubishchev A. (2000). Linii Demokrita i Platona v istorii kul'tury [The traces of Democritus and Plato in the history of culture]. St. Petersburg, Publishing House "Aletheia".

Lloyd, G.E.R. (1979). Magic, Reason and Experience. Studies in the Origin and Development of Greek Science. Cambridge University Press.

Losev, A.F. (1988). Istoriia antichnoi estetiki. Poslednie veka (VIII-VI veka) [History of ancient aesthetics. Recent centuries (8- $6^{\text {th }}$ centuries)]. Moscow, Publishing House "Iskusstvo", 447 p.

Losev, A.F. (1993). Antichnyi kosmos i sovremennaia nauka [Ancient Cosmos and Modern Science]. In Bytie. Imia. Kosmos [Being. Name. Cosmos]. Moscow, "Mysl”", Russian Open University.

Marinus of Samaris (1925). Prokl, ili O schast'e [Proclus or Concerning Happiness]. Translated by Kenneth S. Guthrie. Available at: http://www.plato.spbu.ru/TEXTS/diogenl/marin01.htm

Martijn, M. (2010). Proclus on nature (philosophy of nature and its methods in Proclus' Commentary on Plato's Timaeus). Leiden; Boston, Brill.

McDonald, G.C. (2009). Concepts and Treatments of Phrenitis in Ancient Medicine. Thesis L9158. Newcastle University.

Mesiats, S.V. (2007). Sovremennaia nauka i platonovskii mif [Modern science and the Platonic myth]. Available at: http://www.plato.spbu.ru/CONFERENCES/2002/10-2.htm

Mesiats, S.V. (2009). Nachala metafiziki Prokla [origins of Proclus' metaphysics]. In ARKHE. In Trudy kul'turologicheskogo seminara [ARCHE. Proceedings of a cultural seminar]. Vol. 5. Moscow, Russian State University for the Humanities, 203-235.

Mesiats, S.V. (2012). Proclus's Dyadochus. "Timaues" Commentary. Book 1. 17a-27b. Moscow, "GDK", 385 p.

Orficheskaia tablichka [Orphic tablet]. Fragmenty sochinenii rannikh grecheskikh filosofov [Fragments of the writings of early Greek philosophers. Pp. 43-44. A 1 Zutz (1 B 18 DK = F 32c K.), Furia (Southern Italy), between 400 and 350 BC]. 
Pearcy, L.T. (1983). Galen and Stoic Rhetoric. In Greek, Roman and Byzantine Studies, 24, 259-272. Phillips, J. (2007). Order from Disorder. Proclus Doctrine of Evil and its Roots in Ancient Platonism (Studies in Platonism, Neoplatonism, and the Platonic Tradition), Brill Academic Publishers.

Plato. (1994). Gosudarstvo [State]. Translated into Russian by A.N. Egunov. Moscow, "Mysl”, 79-420.

Plato. Timey [Timaeus].

Proclus Dyadochus (2012). Kommentariy k "Timeiu". Kniga 1 [Commentary on "Timaeus". Book 1]. Moscow, Greco-Latin Cabinet.

Proclus Dyadochus. In Kommentariy na "Timeia” Platona [Commentary on Plato's Timaeus]. Available at: http://centant.spbu.ru/plat/proklos/works/tim_1/000.htm

Prolygina, I.V. (2011). Galen Pergamskii i ego traktat "O tom, chto nailuchshii vrach est' takzhe filosof". Antichnaia i srednevekovaia filosofiia [Galen of Pergamon and his Treatise "The Best Doctor is Also a Philosopher". Ancient and medieval philosophy], 82-92. Available at: http://iph.ras.ru/uplfile/histph/ yearbook/2011/hphy-2011_prolygina.pdf

Puchkova, Ie.A. (2013). Aleksandriiskaia Shkola i dogalenovskiye teorii v meditsine [The Alexandria School and pre-Galen theories in medicine]. In Istoricheskie, filosofskie, politicheskie i iuridicheskie nauki, kul'turologiia i iskusstvovedenie. Voprosy teorii i praktiki [Historical, philosophical, political and legal sciences, cultural studies and art history. Issues of theory and practice]. Tambov, "Gramota", 12 (38), 1, 153-156.

Santillana, G.De (1961). The origins of scientific thought (from Anaximander to Proclus, 600 D.C. to 300 A.D.). New York, New American Library of World Literature.

Scherbenske, E.W. (2009). Canonizing Paul: Ancient Editorial Practice and the Corpus Paulinum. Thesis for the Degree of Doctor of Philosophy.

Schmidt, K.E.A. (1842). De Timaeo Platonis ex Procli commentariis restituendo. Stettin.

Slovar' Antichnosti [Dictionary of Antiquity] (1989). Moscow, "Progress".

Smith, W.D. (2002). Hippocratic tradition. Electronic edition.

Solopova, M.A. (2012). Vita brevis: k tolkovaniiu pervogo aforizma Gippokrata [Vita brevis: on the interpretation of the first aphorism of Hippocrates]. In Filosofskii zhurnal [Philosophical journal], 1(8), 5-25.

Theognis of Megara (1931). Translated by J.M. Edmonds. Available at: http://www.perseus.tufts.edu/ hopper/text?doc=Perseus\%3Atext\%3A2008.01.0479\%3Avolume\%3D1\%3Atext\%3D11\%3Asection\%3D1)

Tracy, T.J. Plato, Galen and the Center of Consciousness. In Illinois Classical Studies, I. 43-52.

Visconti, J.G. (2009). The Secrets of Health; Views on Healing from the Everyday Level to the Printing Presses in Early Modern Venice 1500-1650. Dissertation in History.

Whittaker, T. (2005). The Neo Platonists a Study in the History of Hellenism. Whitefish, Mont., Kessinger Pub. 


\title{
Теоретические и эпистемологические принципы \\ античного естествознания
}

\section{Н.П. Копцева, К.В. Резникова}

Сибирский федеральный университет

Российская Федераџия, Красноярск

\begin{abstract}
Аннотация. В статье рассматривается проблема методологии античного естествознания на материале анализа фрагмента 29cd «Тимея» Платона, Комментариев к данному фрагменту, которые были написаны Проклом Диадохом. Особое внимание уделяется пониманию науки в философии Платона как «правдоподобного мифа», «вероятностного знания», єiкó $\tau \alpha \mu \tilde{\theta} \theta \mathrm{ov}$. В связи с этим рассматривается по-

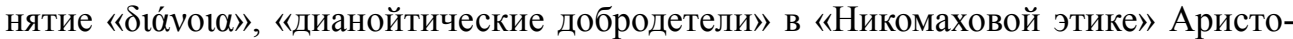
теля и Комментарии Аквината к фрагментам «Никомаховой этики», где говорится о дианойтических добродетелях. Труды великого античного врача Клавдия Галена определяются как универсальный эталон научного познания. Более подробно

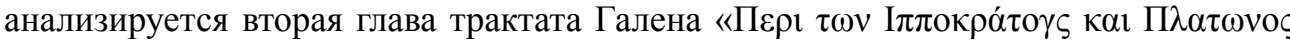
$\delta о \gamma \mu \alpha \tau \omega v »$, рассматриваются основные элементы научного метода Галена.
\end{abstract}

Ключевые слова: Платон, Аристотель, Аквинат, Прокл Диадох, Клавдий Гален, «Тимей», «Государство», «Никомахова этика», античное естествознание, научный метод Галена, комментарии к «Тимею», «Об учениях Гиппократа и Платона».

Научные специальности: 09.00.00 - философские науки; 24.00.00 - культурология. 